2 - 1 緗䒩用主要㽞種の悈性について

第、報定植、，2年目における活着上生育程度の㽞種間差 *鳥丸荻夫、㴊之上康元

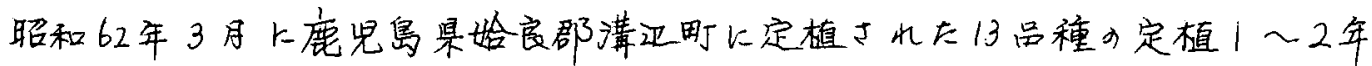
目上おける活着々生育程度について調查走行つ上。試駼区は、定植时の背龄 によク2区分に供試㽞種とにては、2年生苗区としてあさつ中、かなやみど

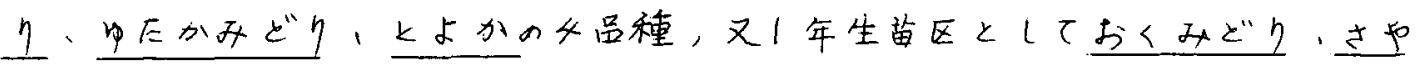

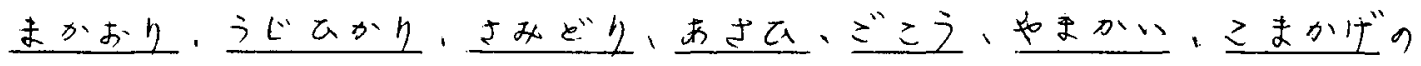
8品種とし兰れぞれやがきたを対照品種として計13㽞種を用いた。

又反復は6ブロック制、1 品種1 プロット15株植之、栽植距離は1.8 $\mathrm{m} \times 30$ 的の1条植之である。調查項目としては、(1)定植)年目の活着率と樹高(12 月)，(2)定植1 2 2 年目越冬率と活着率( 4 月) , (3) 定植2年目の倠察

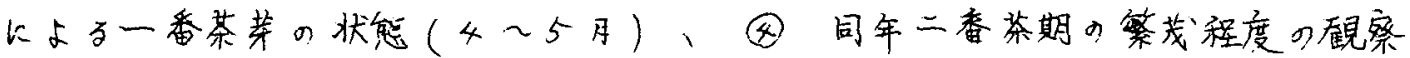
(6月)，司同年秋の生育程度（10月）９5項目で、、ずれも1プッ卜当 り 10 株につき調查した。

本年6月までに得られた結果を要約すると下記のとおりであつた。

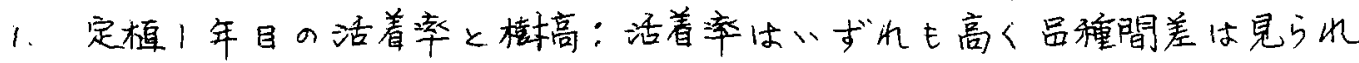
なかつたが、樹高では2年生苗区でやぶきた、上なかに対し五さつ巾、

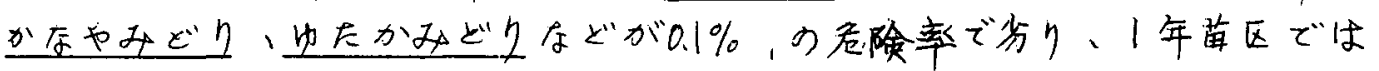

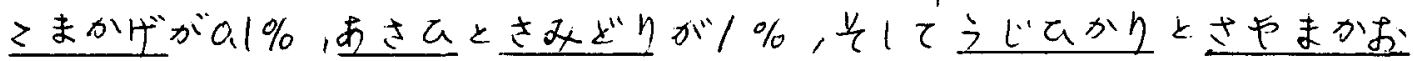

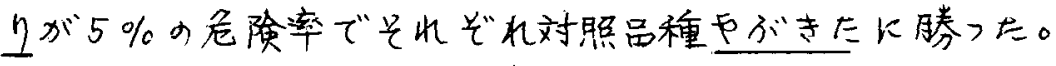

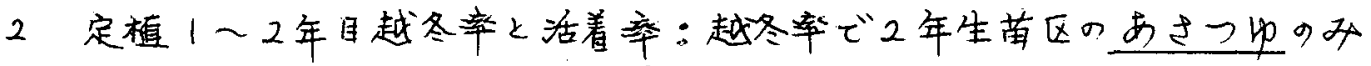

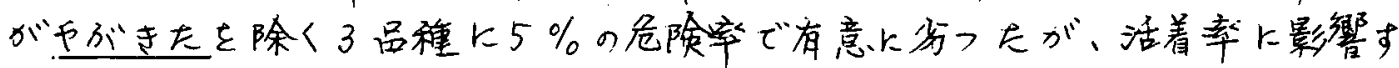
る程ではなか〉た。

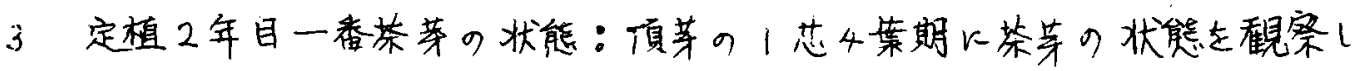
たが、あさっゆとさみどりは第立ちが䔡くしかも小芽であつたのに比較し、 さやまかおりは芽立ちが良好で大芽であつた。

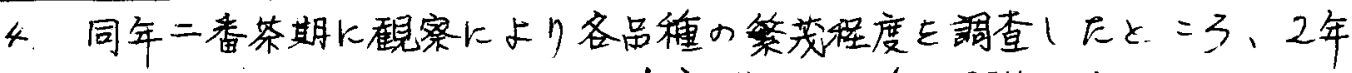

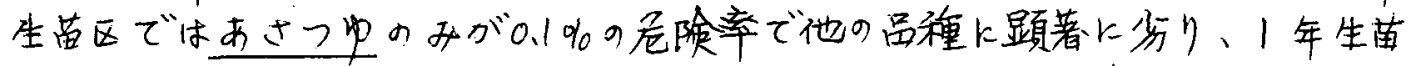
区ではさやまかおりのみが他のすでての呙種よりも蹎著に睠り、送上さみご クは最も劣る傾向であった。

なお，最終的な秋の生育程度については、目下成績をとりまとめ中で、発表 当日報告の予定である。 
2 - 2 粶荼用主要品種の特性について

第2 教定植2年目におりる分玟性の品㮔閏差

$$
\text { 㴊之上康元・身丸萩夫 }
$$

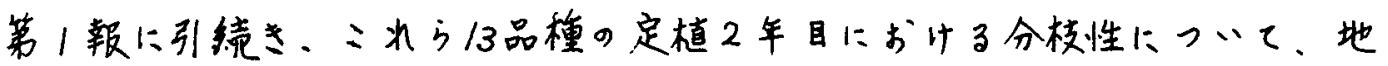

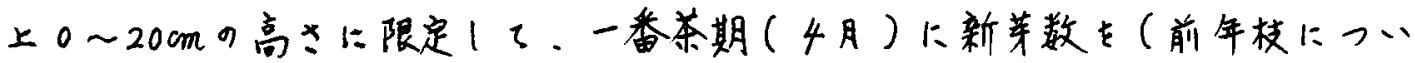

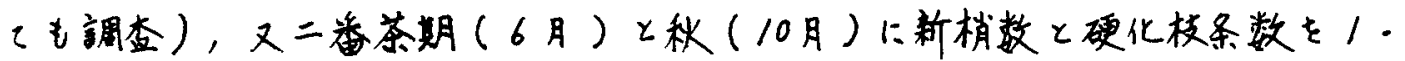
2 次分校别に淍查し。秋には来春の初包世人枝法の基整资料々得る目的で、 樹形，分枝角度，㑯侧枝の長只の比などについても拥查した。6月までに得

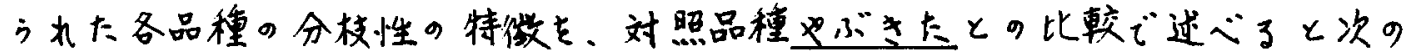
とおりであった。

1. 定植当年の主校数：定植当年にすでに地中で分枝していて我育したもの と思为れるもので地際部径が 6 m 生苗区95品種は平均1.3〜1.7本に变異(品㮔間差はなった。しいし/年

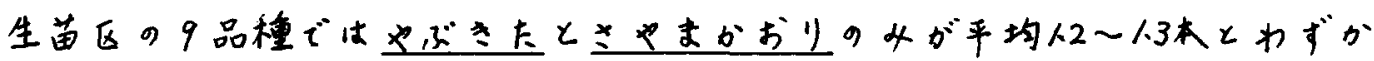
に/本以上で、他の7品種がほとんど/本のた为顕者な有意差がdられた。

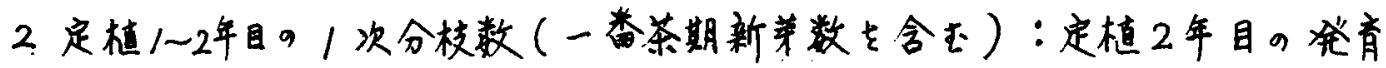

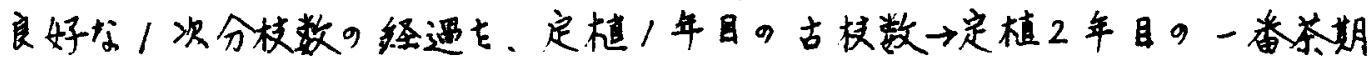

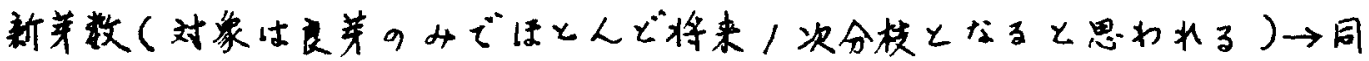

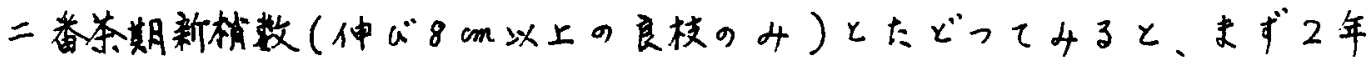

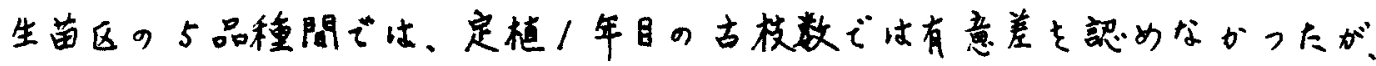

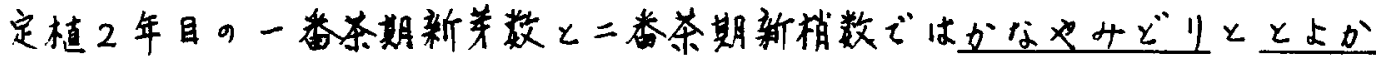

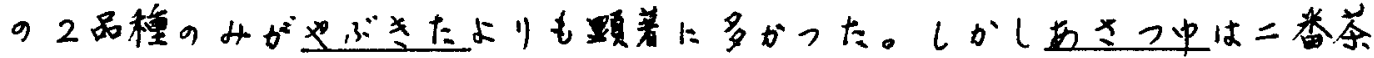

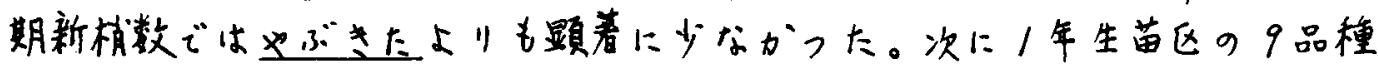

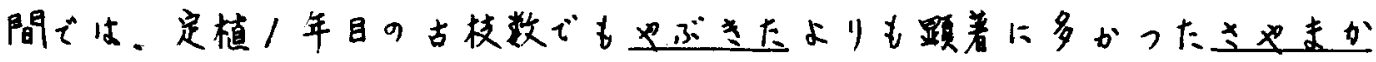

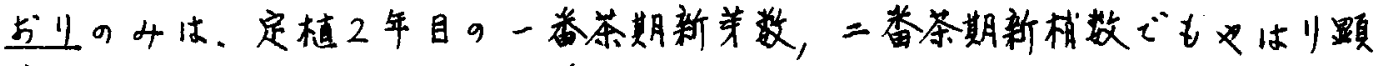
着に多かった。又关の他の品種で特微あるものとしては、おく中どりが二

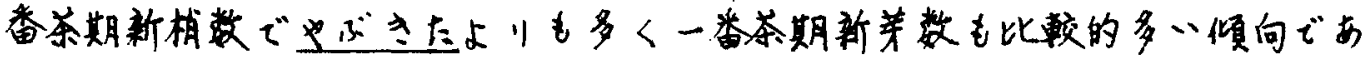

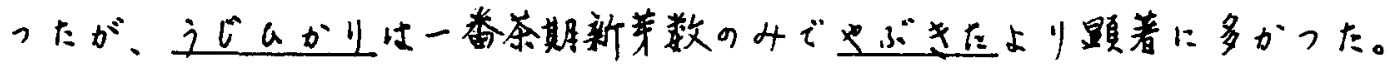

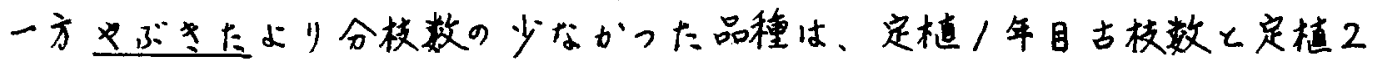

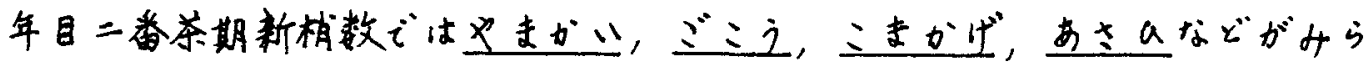

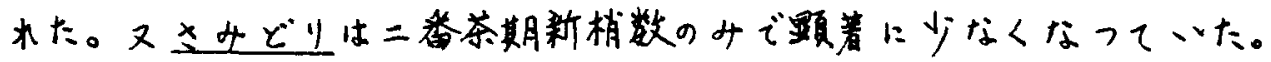

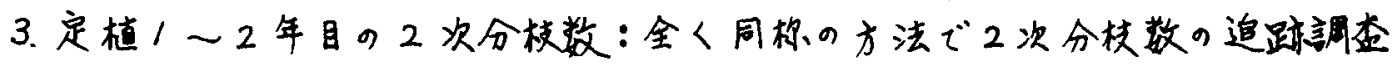
を行つたが、乥の结果は2次分校数はまだ极のて少なく、品程間差では、

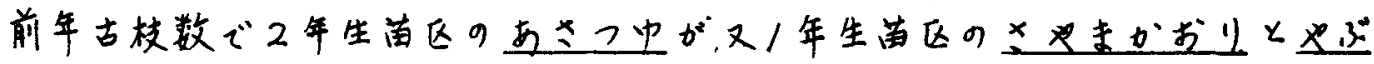
态太が他の品種よりも多かったが、二畨茶期新梢数には差を認めなかった。 なお、秋の分枝性の拥查稓果については、目下とりまとめ中である。 
(熊本県茶業試験場)

村田達郎・宫司佑三

(九州東海大学農学部)

チャは遗伝的に雑ばくであり、しかも自家不和合性の他殖性植物であるた め、交配によって純系を作ることは不可能に近い。しかし、葯培養によって 花粉起源の半数体植物を作出し、それを倍化することによって紝系を作る技 術が確立されれば、チャの遗公解析、育種年限の短繀、さらには種子まき栽 培用品種の育成等、チャの育璉を進める上で役立つことが考えられる。

そこで、チャの萂培養法を開発するため、カルス形成および植物体再分化 の条件について険討した結果、萂から肧様体(不定肧)を形成させ、その肧 様体を継代培養して、植物体を再生させることができたので報告する。

供試䒺は、品種おくみどりの1核期の花粉粒を含む䒺を用いた。植付培地 は、 $\mathrm{N} 6$ （Chu 1978）の基本培地にミオイノシトール $100 \mathrm{mg} / 1$ を加え、2,4ジクロロフェノキシ醀酸 $0.05 \mathrm{mg} / 1$, カイネチン $0.2 \mathrm{mg} / 1$, ショ桾 $60 \mathrm{~g} / 1$ を 添加した液体培地で、PHは5.7に調整した。この培地で $28{ }^{\circ} \mathrm{C}$ ・暗黒条件下 で75日間培養した葯を、再分化培地のN 6 基本培地にミオイノシトール 100 $\mathrm{mg} / \mathrm{l}$ を加え、カイネチン $1.0 \mathrm{mg} / 1$ ，ショ楉 $50 \mathrm{~g} / 1$ を添加した寒天培地に移 植し、 $28^{\circ} \mathrm{C} ・ 16$ 時間照明下で培養したところ：カルス化していなかった䒺か ら肧様体が形成された。

この肧棣体を葯から分離して、N6 基本培地にインドール酪酸とジベレリ ン酸を各 $0.5 \mathrm{mg} / 1$, ショ愇 $30 \mathrm{~g} / \mathrm{l}$ を添加した寒天培地に移植した。その後も ベンジルアデニン，ゼアチン等を添加して、ホルモン条件の巽なる数種類の 培地で継代培養し、罘様体の発有を促したが、約 9 ケ月経過しても幼植物体 の形成まてに至らず、カルス化した。

そのカルスを分割して種々の培地条件で継代培養を続けたところ、5倜の カルスからシュートが伸興して幼植物体が形成された。さらに、この肧様体 由来のカルスからはその後も植物体が数多く形成されており、再分化能の高 いカルスであることが望められている。

再生した植物体の枝条を先端から $3 \sim 5 \mathrm{~cm}$ の長さで切り取り、基部の約 $1 \mathrm{~cm}$ tをインドール酪酸 $0.5 \mathrm{~g} / 1$ 溶液に 20 分間浸清した後、W P M (L.1oyd \&McCown1981)の基本培地にショ拮20g/lを添した液体吙紙床培地に植え 付けることで、発根させることができた。発根した佃体はバーミキュライト ・ピートモス・ボラ土を等量に混合した培養上に移植（鉢上げ）した。

順化中の 4 個体の根端槒胞の染色体数を调查した結果、30本であった。 
$2-4$ ‘やぶきた’における葉緑変異体の出現率と化学成分

鳥屋尾忠之・・川田真佐枝

(農林水産省野莱・菜業試験場)

通常の载培茶園でも自然に発生した葉色の变異枝条がしばしば珰められる。 これらの緑色・黄色の渴さの变異は、葉に含まれるクロロフィルの量・䁈の 变異によると思われるが、クロロフィルは物䝷代謝、特に光合成に関与して いるので、その場合、アミノ酸等、他の成分の含有量にも変化が起きている 可能性がある。チャの葉に含まれる化学成分は、製茶の品唄を決める大きな 要素であり、品理育成の上でも重要視される。そこで、野菜・茶業試駼場の 囷埸で㮩出された葉緑変異枝条に着目し、その出現率を調查するとともに、 茶の品㙺に関与する、アミノ酸、カテキン、カフェイン等の化学成分の含有 量を調査した。

材料と方法

変異発生率の調查：1985，1986年に、試騙埸内の“やぶきた’の团埸を中心 に葉色の異なる枝条を調査し、単位面積当りの枝条数から算出した䌊枝条 数を用いて、要異枝条の発生率を計算した。

成分の分析：葉緑変異枝条の一部を㨉木盖成し、均一な栽培条件下で試料を

採取して分析に供試した。クロロフィルはComar法、総アミノ酸、カテキ ンは、それぞれニンヒドリン法、酒石酸鉄法によって分析し、一部の材料 についてHPLC法で主要アミノ酸類の分別定量及びカフェインの定量を行つ た。

結果

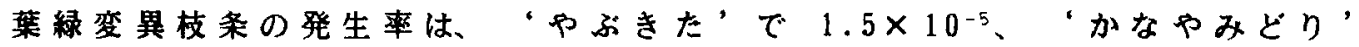

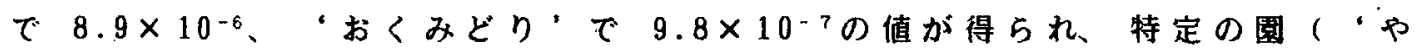
ぶた：東 3 号園，南10号園の1949年定植)で発生率が高いことが判った。

クロロフィルa, bの含有量は原品種よりも少ないが、装異体間の差異は 大きい。また、 $\mathrm{a} / \mathrm{b}$ 比は2前後の值であった。総アミノ酸は、原品種 やゃ

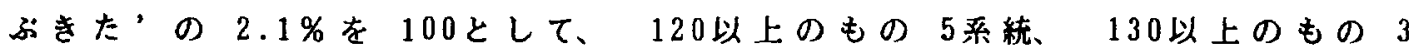
系統が得られ、最も高い系統は1450值であった。アミノ酸とカテキンの含 量には負の相関関係が認められた。特定のアミノ酸のみが顕著に多い、ある いは少ない系統は検出されなかった。また、アミノ酸とカフェインの含量に は正の相関関係が諰められた。

以上の結果加ら、葉緑変異枝条の中から高アミノ酸等、化学成分变異体を 得られることが明らかになった。今後これらの材料を対象に、南種秦材とし ての㛟討を行う予定である。 
$2-5$ 茶品種のアイソザイム变異について

・池田奈実子・川田直传枝・武田善行・鳥屋尾忠之

(㤟林水産省野菜・茶業試験場)

チ十の育種において，近縁種から新たな遗伝子を迹入することにより。新 しい嗜好飲料向き品種，あるい低コス卜生産のため高度障害抵抗性をむっ

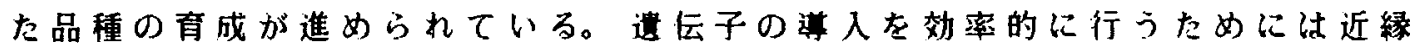
種の類縁関係が明らかにされていることや。育成された雑種の確認が必要で あるが、従来の形態的な形質に上万分類・識別のみでは不十分である。ここ で㹥生化学的な手法としてチャのアイソサイムに上万分類・識別法の唡討を 行い, チャ品種のアイソザイムを調べた。

チャおよびカメリア属のアイソザイム分析は. I.E.Bakerら. 淵之上(1974. 1975). 長戸(1979.1980.1982). Xuら(1987). Wendelら(1982)によつて行わ れている。しかし、チャの電気泳動は醇素がホリフェノール類の影椊を受什 るため鮮明なバンドが得られず解析を困蜼にしてきた場合が多いので、本試

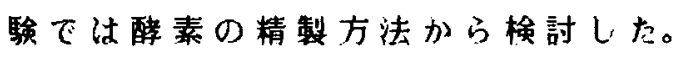

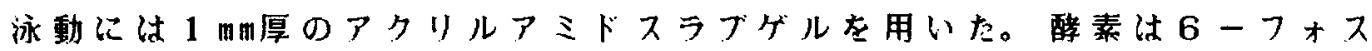

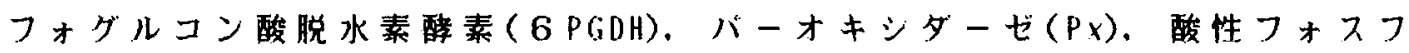
オターゼ(AP)を报った。試料の抽出から泳動まではすべて 4 叫の低温室内で 行った。ボリフェノールを除去するために, 試料磨砕時のポリクラーAT添加。 セファデックスら-25力ラムによる脱堛. ブルーセファロースカラムによる精 製を試みた。ブルーセファロースカラムは，6PGDHについては最も有効て 1

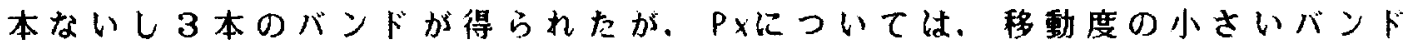
は鮮明になったが移動度の大きいハンドが消失した。AP过上記の精製方法で は安定したバンドは得られなかった。

6 PGDHのバンドを上から $P_{1} ， P_{2} ， P_{2}$ とすると、日本種では $P_{1} ， P_{2} ， P_{2}$ の 3

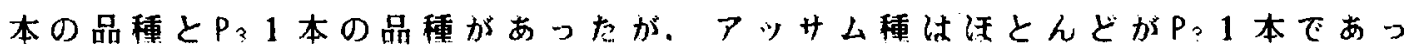
た。 6 PGDHは他の植物では 2 电体であるとの報告が多く. Wendelら(1982)も ツバキの6PGDHは 2 体てあると報告している。P、Pミ1本をもつ屯のの遗

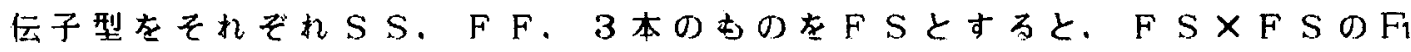

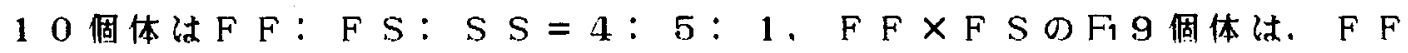

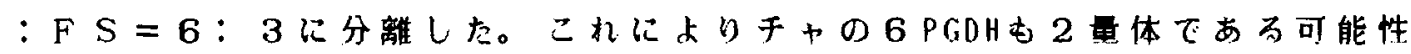
が示唆された。

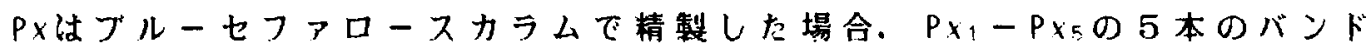
が確認されたが、日本種は“やぶきた”などPメa1本のバンドをもつものが

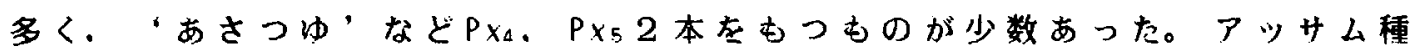

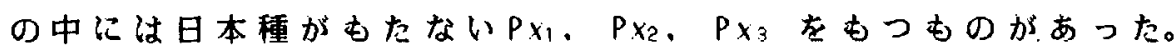


2 - 6 アイソザイムによる茶の品種分類の可能性

谷博司

(静岡紧茶業試験場)

作物の種・系統の分類は徒来から形態的な差異によって行われてきた、し かしこのような形熊的形質は環境变異が大きく多数の個体を扱う必要があっ た、近年この方法に加えてアイソザイムや化学成分による手法が取り上げら れ多くの研究が成されている。茶でもアミノ酸やカテキンにより品種分類が 可能とされているが、バラッキが大きくた高度なテクニックが要求される、 アイソザイムはサンフルが少量で比较でき、短時間に検出が容易である、茶 でも長門（１９７９）洲之上（１９７5）等の報告があるが品種間の变異に 重点がおかれ品種内变異にまで言及していない、本研究は簡易に品種の同定 が可能なアイソザイムの手法を検討した。

植物にはホリフェノールと推定される醇素活性阻害物筫が多量に含まれて おり蒸留水等で抽出しても醇素活性がみられないことが多い、このため様々 な阻害物筫抑制剷が利用されており茶ではP V P とトリトン(TWEEN X-100)が 有効と思われた。

供試茶樹は日本の品種、系統 2 1、中国種 8、アッサム種8を使用し、エ ステラーゼ(EST)およどパーオキシターゼ(POX)の 2 種類の醇素について比㜞 したが系統によってはどちらか一方の酳しか报えなかったものもある。

泳動は中川原（１９７８）の方法に従い寒天＋PVPの平板溥層法を用い た、E STではバンドが5本㮩出されザイモグラムは7種類に分類てきた、 またPOXでは陽承侧に6、陰極侧に4本のバンドが見られたが陵苏側のバ ンドは安定しておらず検討対象から除外した、踼苏侧の6本のバンドだけで P OXでは 13 種に分類され、E S TとPOXの二つの醇素を検出した 28 品種、系統を分類すると17種に分類された。

供試した材料の中で親子関係が明らかな品種系統の数が少なく特定バンド の遣伝関係は明かてない、しかしザイモグラムバターンの变異は中国種で大 きく日本種では比較的小さいと思われた、アッサム種は材料をガラス室から 採取したものが多く明瞭なバンドの検出ができなかった、今後供試する品種 系統の数や、検出するアイソザイムの種類を多くすればかなりの品種の判別 が可能となり、また特定形筫のMARKERとして幅広い利用が可能となると思わ れる。 


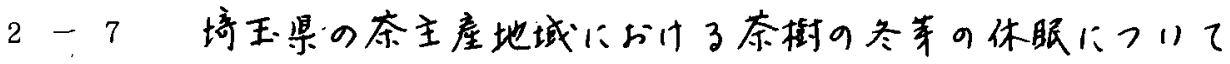

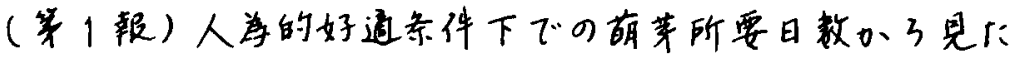
冬莱の休眼9实態

汶之上弘子

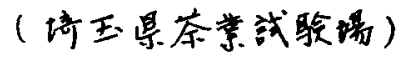

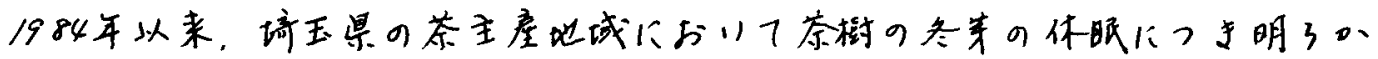

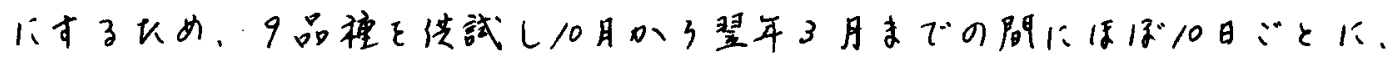

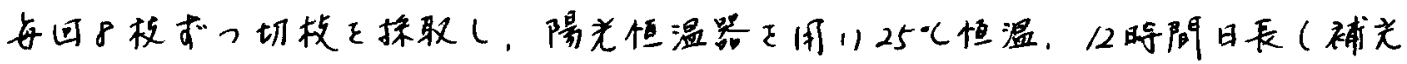

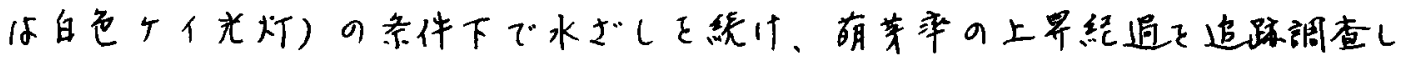

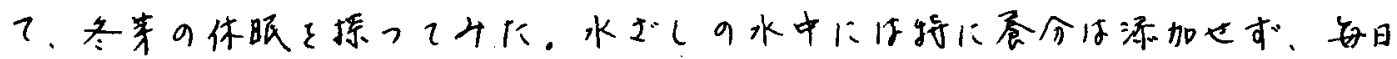

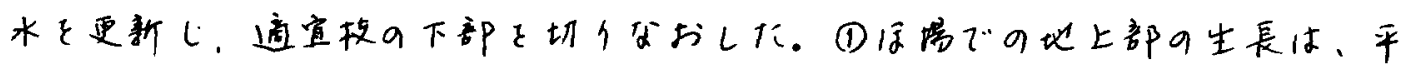

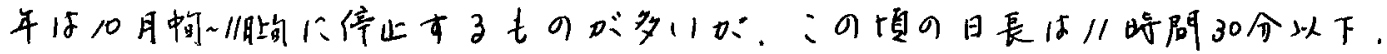

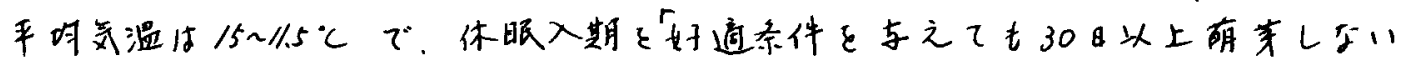

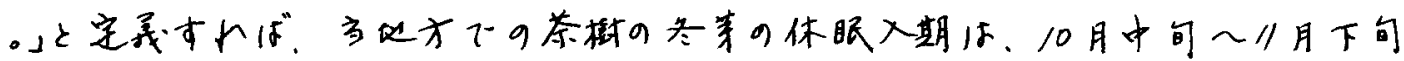

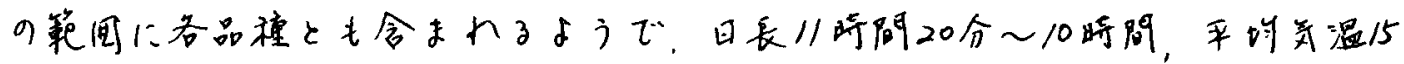

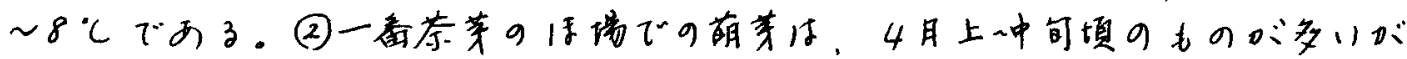

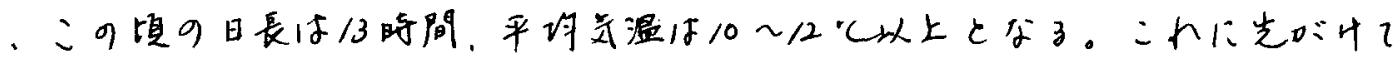
2月中旬〜3月下旬には，好通条件下で10日以内人有萃は30\%以上の上异

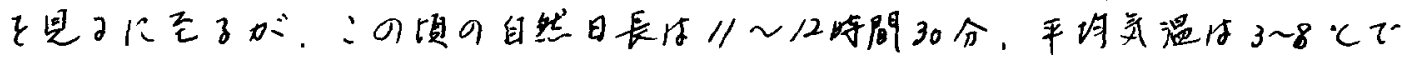

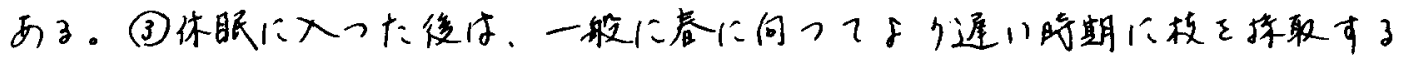

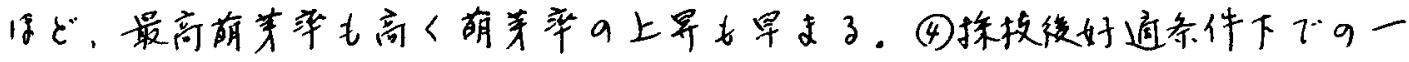

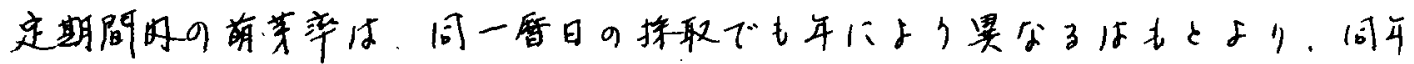

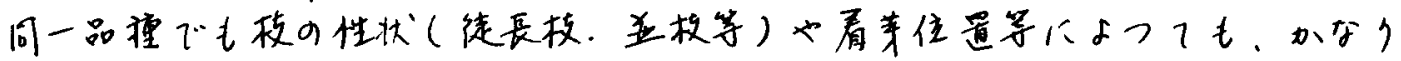

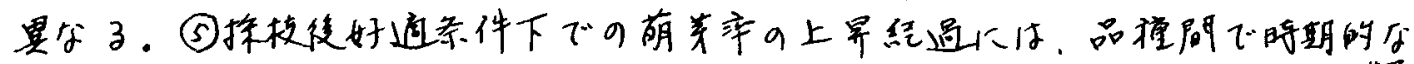

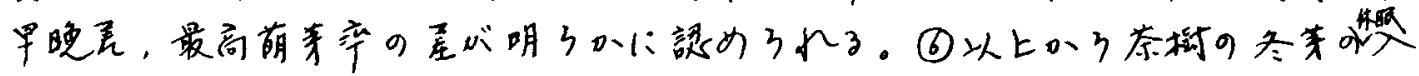

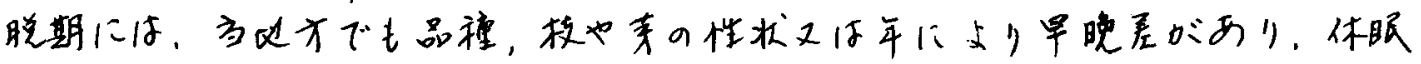
の深さにも差ロ゙西るなうに推察される：(9奈树の冬茅の休眠のもつとも源い

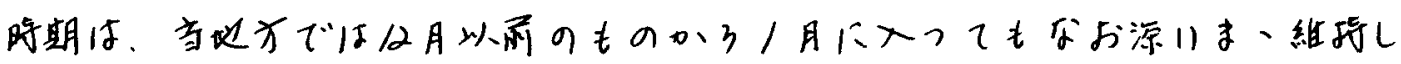

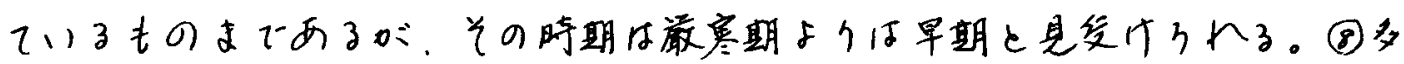

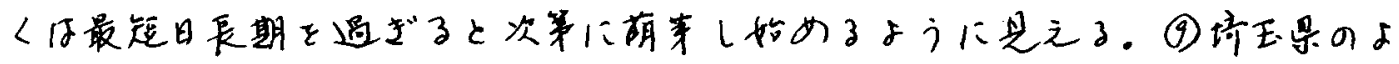

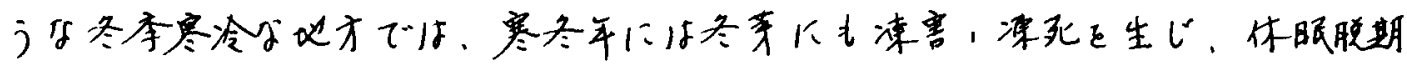

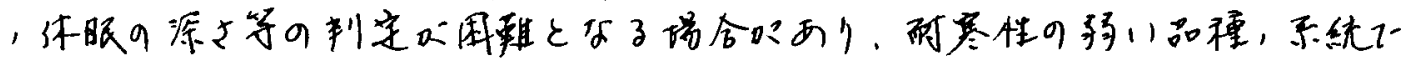

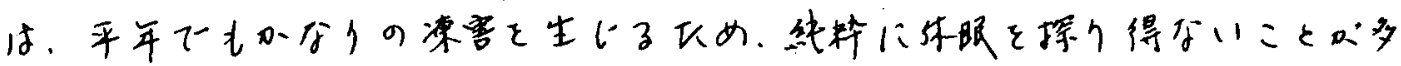
い是壬判明しK。 


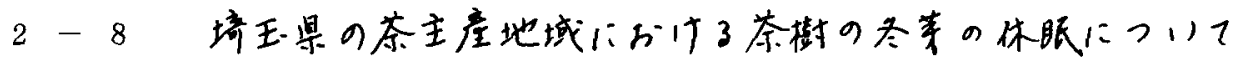

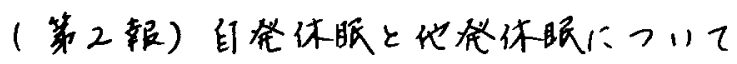

椡之上弘子

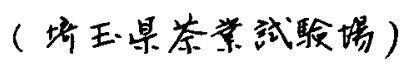

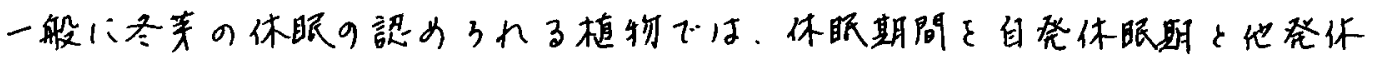

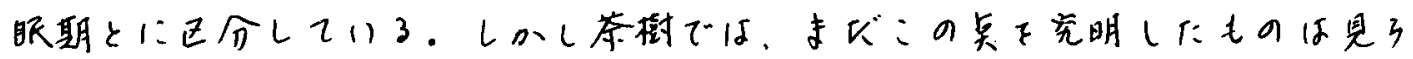

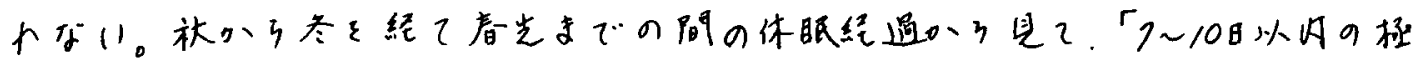

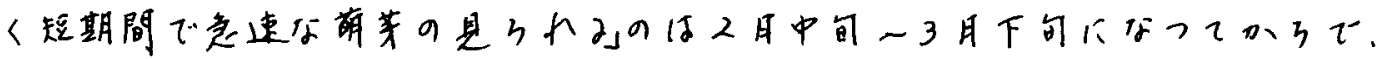

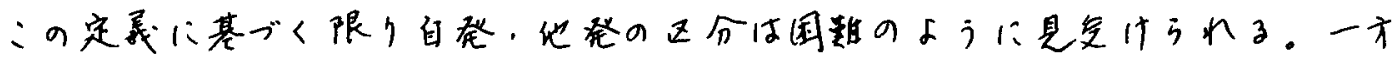

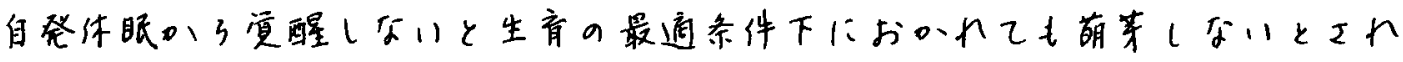

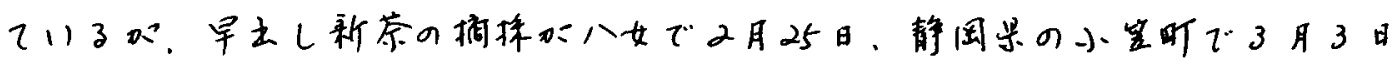

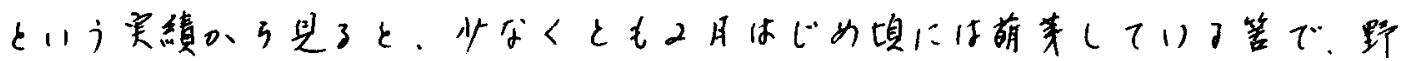

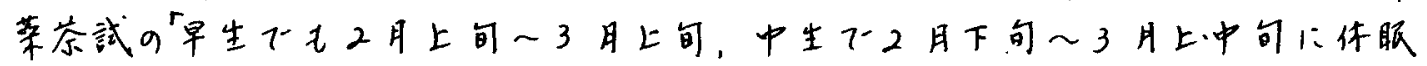

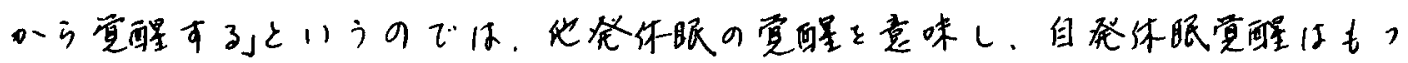
と早期にあるものと考之られる。自発休眼䆓醒期の基準は。植物によつても

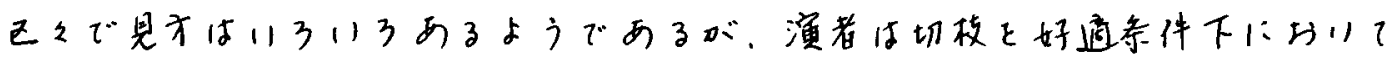

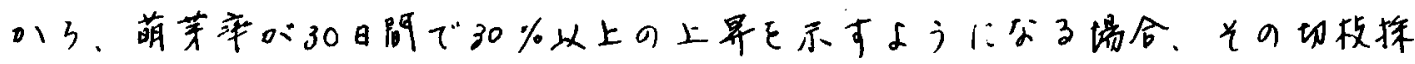

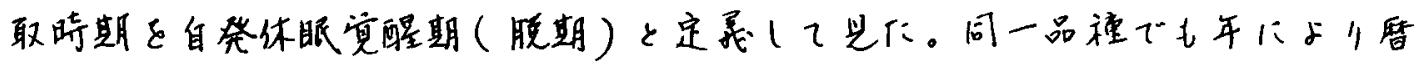

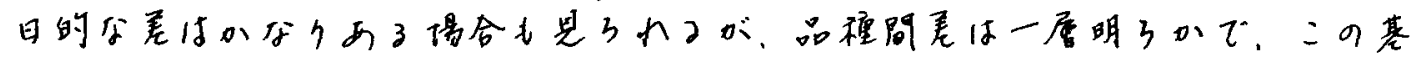

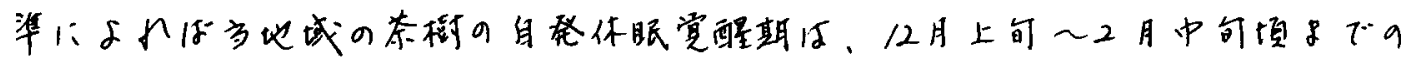

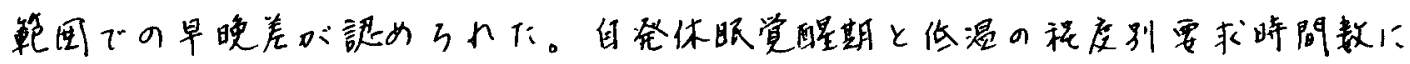

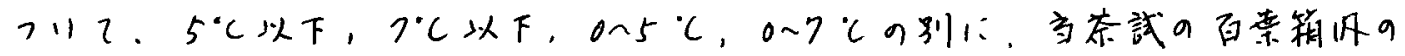

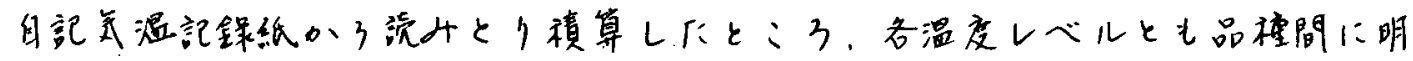

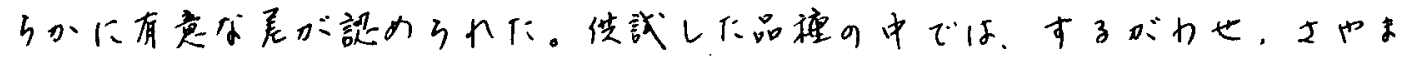

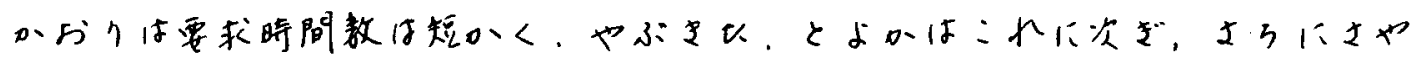

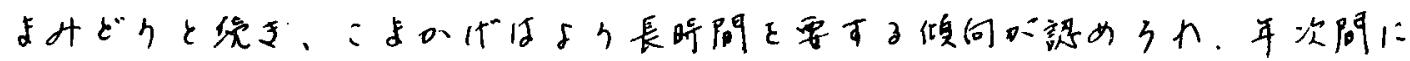

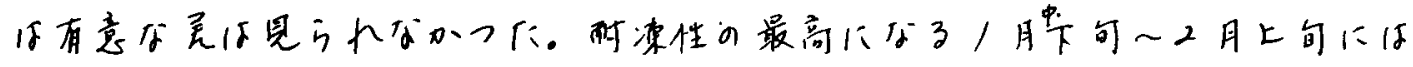

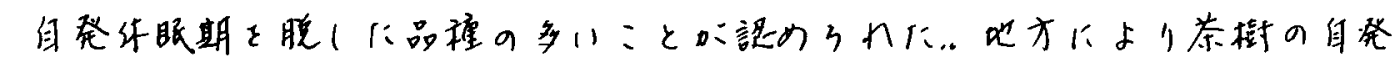

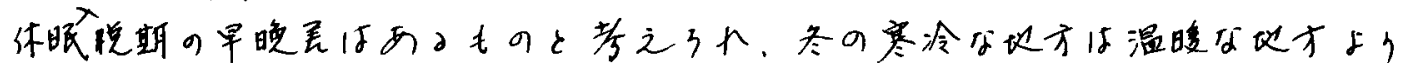

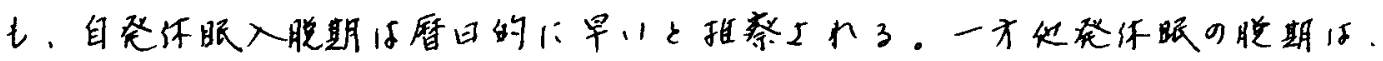

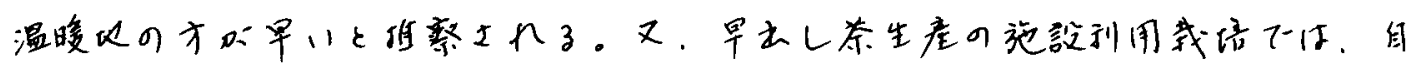

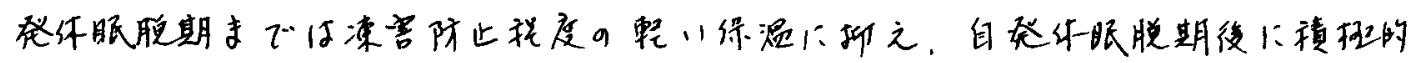

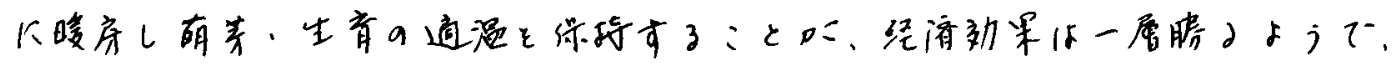

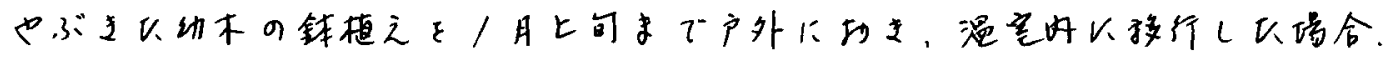

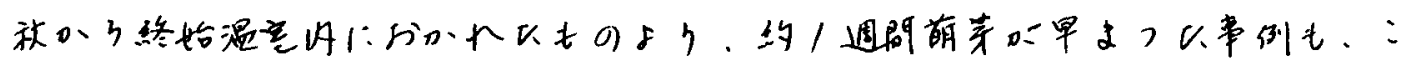
クを变付けていると考之る。 


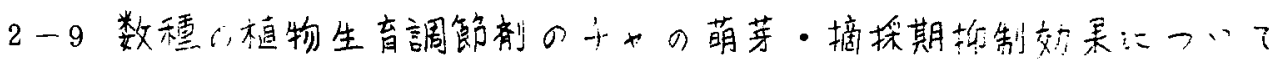

米谷力・濑川賢正

（奈良杲農試荣業分場）

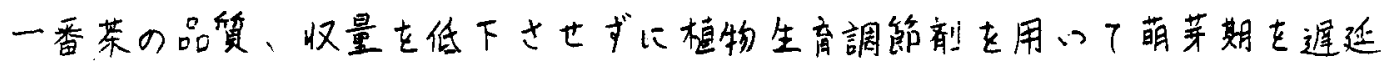
させ凍霜害を回避するとともに摘採期を調跑する試みをし若千の結果を得た ので報告する。

1987、1988年の一番荣萌茅10〜20日前に表に示した率剂を散布するととも に1988年は整枝時期と植物生育調節剂処理を組合せて、一番荣萌芽期、摘採 期ならでにその後の生育に及ぼす影響について調查した。

1)供試した菜剂すべてに萌芽期の遅延効果が認如られた。菜剂間で萌芽 崌延に対する影響の違いは明らかでなかった。菜害の出現しない籁囲内での

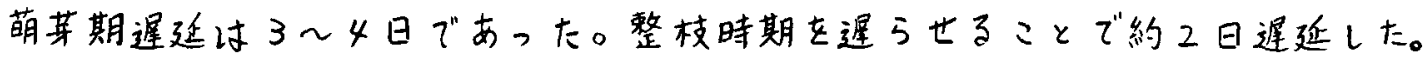

2) 供試した葉剂で葫芽期を革延させることで凍霜害被害を軽減すること が可能であった。茶剂間での䔔いは明らがでなかった。

3）萌期の暒延にともなって摘埰期も崌延した。

4)収量大らでに製茶品質については蔽処理による影響は少ないように 思われた。

5)一番荣以降の生育についてはパクロブトラゾールを除いて影響は少で あったが、パクロブトラゾールはニ番荣ならでに秋芽の生育量も劣つた。

6)蔡剂処理による寒害被害に対する影響仙秋芽の生育量の劣ったパク口 ブトラゾール矢で赤枯れが大であった。

7) 萌茅期約20日前にジゲグラック90 ppm、MCP500 ppm、工于ク口ゼ 一ト1000 ppm以上の濃度で処理すると菜害が出现した。

表 供試菜剂な弓でに濃度

\begin{tabular}{|c|c|}
\hline 葲刘名 & 濃度 \\
\hline ジゲグラック & $3.6 \sim 90 \mathrm{ppm}$ \\
\hline$M \subset P$ & $100 \sim 500 \mathrm{pP} m$ \\
\hline エチクロビート & $100 \sim 1000 \mathrm{ppm}$ \\
\hline パクロブトラン゙ール & $2000 \sim 4000 \mathrm{ppm}$ \\
\hline $\mathrm{KUH}-833$ & $500 \sim 2000 p p m$ \\
\hline
\end{tabular}


$2-10$ チャ新芽の硬化度測定法とその応用

”佐波哲次. 渡辺利通. 田中静夫. 青野英也

( 農林水産省野菜・茶業試験埸)

チャ新芽の熟度（摘採期判断の指標となるもの）は，経験に基ついた「手 ざわり」などで決定されている。これはかなり主観的なものであり，個人に よるはららつが大きいため，客観的に熟度を測定する様々な手法が検討され てきた。演者らは新芽形賀の硬化度に着目し，それを数値化することによる 熟度判定を検討した。

昭和 60 年から63年の 4 力年，摘採適期前から明らかに品質の低下が認めら れるまで硬化度を測定した。硬化度はレオメーター(不動工業)による切断 力で表した。またデジタルフォース・ゲージ(シンポ工業)で茎の折り曲げ たときの力 (挫折力) を測定し, レオメーターで得られた切断力との関俰を 検討した。

1. 葉位别・節位別に硬化度の推移をみると, 最下位葉の硬化の進行はきわ めて早かつた。新芽の荎についても同様で茥の下部ほど硬化の進行は早かっ た。葉と萃を比較すると荎の方が硬化は急速に進んた。

2. 茎の太さ（（長径十短径）/2）と硬化度との関係は，1，5 mm 程度まで は太くなるにしたがって硬化度も增加したが, $2 \mathrm{~mm}$ 程度になると蒸の硬化度 にばらつきが目立つようになった。このことは荎の生育がある程度まで進行 すると硬化のみが進み, 肥大生長が一度停止する可能性を示している。また 同一日に採菒した出開芽とそうでない芽との間には硬化度に大きな違いはな かった。新芽生育がある程度進んだ段階では, 荎の太さや出開きの有無に関 係なく，硬化度を測定することで新芽の熟度が推定できることが推測された。 3. 品種・年次・载培条件にかかわらず, 一番茶では 1 葉目と 2 葉目の間の 茎の硬化度がレオメーターの測定で500 g fを越えるころから急に硬化度が増 し, 同時に荒茶品質も低下することがわかった。このことからこの部分の硬 化度を測定することにより摘採適期を判定することが可能であると思われた。 さらにその後の生葉品筫の低下も数值化するてがかりを得た。しかし二番茶 の場合には生育むらが大きく、はっきりした㖽向は得られなかった。 4.レオメーターとデジタルフォース・ゲージで得られた值の間には, 有意 な相関関係 $(r=0.8070 \%)$ があり, 固場で利用できる後者の機器でも硬化 度測定は可能であると推定された。しかしこれは三番茶で得られた結果であ ク, 一・番茶についてはさらに検討を要する。 
$2-11$ ジケグラック剂による一番茶芽の芽ぞろい向上

*澤崎肇・原田和也

岡井仁志 ${ }^{1}$ ) . 中島博道 $\left.{ }^{2}\right)$

(京都府立茶業研究所)

一般に、自然型仕立て茶園において、手摘みされる一番茶の新芽は、大き な頂芽とそれに比較して小さな䏢芽が混在し、このことが製茶品質に悪影響 をおよはしている。このため製茶品質の向上には、新芽の芽ぞろいを良くす ることが有効である。吉田は、芽ぞろい向上について、夏季摘芯により分枝 を大きく生育させる方法及び生育停止期の摘芯により頂芽を除去する方法を 㛟討し、ある程度の成果を認めている。本研究においては、これまで乎及び 機械によって行ってきた摘芯を、植物生育調節剂のひとつであるジケグラッ ク剂（商品名：アトリナール）で行い、枝条の分枝発生・生長及び一番茶の 芽ぞろい・品質におよ㭱す影響について娭討した。

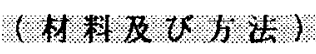

試験 1 .ジケグラック剆の夏季処理効果について：番刚り後に萌芽した二 番芽の生育期に、2 時期・3濃度で散布し、翌年の一番茶期に、分枝の発生 ・生長及び芽ぞろいについて調查した。

試験 2 . ジケグラック剂の秋季好理効果について：秋芽の生育期から生育 停止期にかけて、3 時期・2 濃度で散布し、翌年の一番茶期に芽ぞろい及び 製茶品質について調查した。

\section{(䊁: 果)}

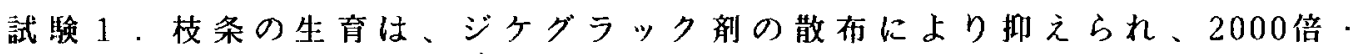
5000 倍液散布区においては、1枝条あたりの平均分枝発生数が、無処理区と 此較して增加した。しかし、分枝の生育は10 cm以下のものが拜とんどであり、 大きな分枝が生育することはなく、芽ぞろいの向上にはつながらなかった。

試験 2 . 無処理区の枝条に生育した一番茶新芽は、頂芽が腋芽に比へて大 きいが、ジケグラック剂を散布した枝条では、無処理区の新芽に比へてて頂芽 が小さく、また服芽が大きくなる傾向が認められ、頂芽と服芽の大きさの較 差は小さくなった。この傾向は、500倍液散布区よりも200倍液散布区にお いて強かった。芽ぞろいについては、12月2日に200倍液を散布した区で優 れて抢り、大きな芽の減少が顕著で、また $10 \mathrm{~cm}$ 以の芽がかなり增加した。 官能検查結果においても特に外観は、同区の点数は高かった。しかし、他の 処理区においては、芽ぞろいが特に向上することはなく、更に検討が必要で あると思われた。

1)現京都府立農業大学校年現京都苻農産普及課 
2 一 12 茶数品種における夏季整枝及ひ生育調節剂

に上る芽ぞろい耑」

*植田和郎・吉出輝久.鳥井清孝

滕井素夫愿出利也、澤崎壁

(京都府立余業研究所)

自然仕立て载培の一番茶期には大小さまさまな新芽が着生し、しかもこれ らが闰時に手摘みされるため原料生葉はきわめて不ぞろいである。新芽がふ ぞろいになる原因として、(1大小さまさまな伎が発生するため、それに着生 する新芽が技間でバラつく、(2)同じ技内の新芽でも頂芽と渡芽の差が大きい ことがあげられる。製茶品質を向上させるには新芽の芽ぞろいをよくする必 要がある。(1)の対策としては、番刈り後生長し始めた婹勢な芽を刚りそろえ 技条の生育を均一にすること（夏季整枝）、また(2)の対策としては、枝条の 生育停止期に頂芽を除去寸ること（秋摘芯）が有効と考えられる。

この研究では、数品種を対象に夏季整枝と秋摘芯によって芽ぞろいを向上 させる技術を㛟討した。なお植物生育調節剂のひとつであるジケグックク剂 (商品名：アトリナール)の秋季散布に高い摘芯效果が認奴たので(澤 崎ら、1988)、秋摘芯にはこれを用いた。

\section{(材料及Uサ法)}

試駘区として夏季整枝区（整枝区）、夏季整枝+アトリナール散布区（整 枝ＡＴ的）、アトリナール散布区（AT区）及び無処理区を設けた。夏季 整枝は7月15日に番刈り面より10c片の高さで優勢な芽を刈りそろえる程度 とし、秋摘芯は10月20日にアトリナール200倍没を10aあたり 200 散布し た。琹年の一番茶期に枝ぞろい、新芽の芽ぞろい及び製茶品質を調查した。

\section{(艧:果)}

1)枝ぞろい：夏季整枝を行った区では此較的短い枝がよくそろって発生 しており、無処理区に比へて枝ぞろいは改善されていた。

$2)$ 新芽の芽ぞろい：整枝区では、䏢芽間での芽長の差は小さかったもの の、大きな頂芽が混在していたため芽ぞろいの向上した品種は少なかつた。 アトリナー゙を散布した区では、無処理区に比べて頂芽が小さく、また服芽 が大きくなり、頂芽と変芽の差は小さくなる傾向が認められた。このため大

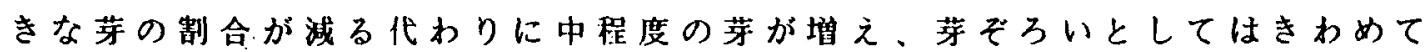
バランスのよいものとなった。とくに整枝＋AT区の芽ぞろいが傮れる品種 が多かった。製茶品質は芽ぞろいの良否と一致する場合が多く、多くの品種 で整枝+AT区の品質が最も擾れていた。

以上より、新芽の芽ぞろいを向上させるには、夏季整枝とアトリナールの 秋季散布を組合わせるのが有效と考之られる。 
2 - 13 高度精整マシン油、被覆資材を利用した

茶樹の寒干風害防止対策

森山新三郎

(長崎県総合農林試験場東彼杵茶業支場)

寒干風害防止対策として、防風林や防風網は経費、労力、葙害誘発、病害 虫の発生源等に問題点が多いため、簡便て実用的な防止対策を検討した。

○高度精製マシン油乳剂

カンザワハダニに登録のある有効成分 $98 \%$ ○シン油を用い、使用澏度、 処理回数、防止効果を検討した。

1984 年㭠雪後に融雪の早い樹冠部加ら青枯れし、風上侧の晆ほど被 害が大きかった。

マシン油処理区は被害が全体に少なく、瀆度別では越冬葉への効果は 50 倍区が優り、春せん枝後には遭度差は認められなかった。

収量は、各茶期とも無処理に対し150\%前後で、被害の軽減効果が高か つた。処理濃度、回数を明らかにするため散布後の葉上残留油分の定量を行 った。マシン油の残存は湄度、被覆との組合せによる差よりも性状によるも のが大きく、高粘度(高分子) のもの活ど残存期間が長く、有勃残存期間は $20 \sim 30$ 日程度と推察され、寒千風害防止を目的に使用する場合の涨度は 100 倍で、被害頻度の高い12月下旬及び 1 月中下旬の 2 回散布が適当と 思われた。

○化䋐力ンレイシャの被墔

品質向上用に用いられる遮光率 $60 \%$ 化織カンレイシャで直接被罯し、 被期間と寒干風害防止効果を榆討した。

1984 年は低温期問が長く処理区も被害を被ったが、無処理に対して被 害葉、枯枝ともに少なく、収量は、一番茶 $170 \sim 230 \%$ 二番茶1 80 〜 $240 \%$ 軽減効果が高かった。被覆期間は、除去が早いと寒のもどりの 影響を受けるため、被害頻度の高い12月下旬から春せん枝までが噢当と思 われた。

○組合わせ処理

マシン油乳剂と被覆の組合わせ処理は単独処理より効果が高い。さらに、 被害は風上側の畦ほど大きく、防風垣等による一次防風をすればより効果が 高いので、寒風の当たりやすいほ場ではこれらの組合わせ処理が必要であろ う。防風垣に汹常緑の常盤ススキが強程で、しかを教料としても活用出来る ので適当と思われた。本技術は連年使用しても茶樹への影暜は見られず、力 ンザワハダニの防除、品質向上用に一般に普及している資材を多目的に活用 出来る点で、赛用性が高い。 
$2-14$ チ十の潮風害回避について

*田中敏弘 - 山中浩文・岩倉勉・澼崎亮

（鹿児島県茶業試験場）

松山康甫

（現鹿児鳥県蛎業大学校䒩業学部）

干十の潮風害の発生は、付着塩分量ばかりでなく、風による機械的損偒も 大きな要素とさ狆ている。著者らは、1985年に除塩然目的として水洗法长試

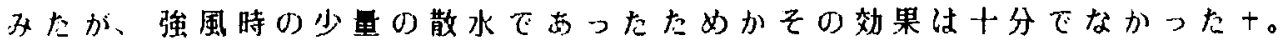
そこて、一方の機械的損偒在防くことを主目的に、夏から秋季に加ての間 作作物の然入效果に着目し、87年に現地調查を行った結果、一定の成果在得 たので㪕告する。

試駼方法

1987年8月30日から31日にかけて、台風12号が九州西海上在上し、その

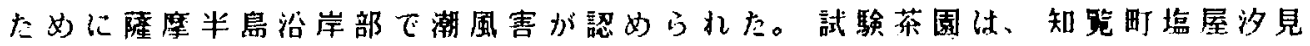
原（海岸からの距離 $4 \mathrm{~km}$ 、標高 $100 \mathrm{~m}$ の平坦地）で、87年 3 月上旬に 2 条千鳥 植ていた加みどりの2 年生苗在栽植したむのでり、5月上旬にソルガム(

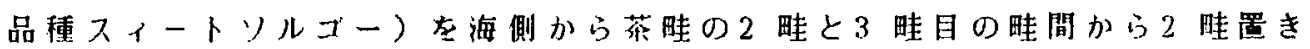
に条播したむのであるソルガムは8月9日に地際部から!回杊取って敷料

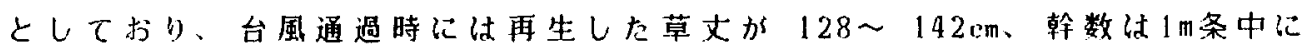
27〜40本に達していた。

台風通過直俊の31日に樹冠面付近の茶芽 $30 \mathrm{~g}$ 在 500 冰で洗浄し、Mohr

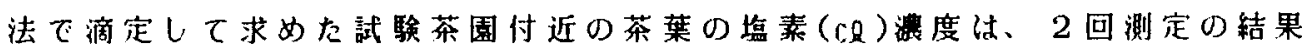
173.9 と $185.8 \mathrm{ppm}$ 苗った。

台風通過後2 日目に被害芽率在、10力月目は枯死株に抜根後補植した株も 含めた枯死株察を調査した。

試験結果並び考察

10 月目の調查では、海侧から䒺轧の1、2 畦目では74.3\%の株が枯死し ており、改植が必要と思わ执た。かし、1 番目のソルガム垣の背後の3、 4 畔目では、17.9\%の枯死株率であったが、2 番目の背後の5、6晆目では5.

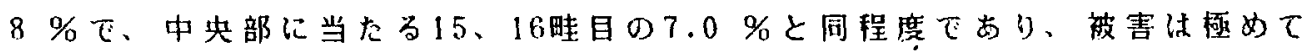
小さかった。

前回(1985年)と今回の試験結果から、台風時の潮風害の回避のためには、 少量の散水よりは防風対策が有効と考光ら机る。また、間作はソルガムのよ うに耐倒伏性の強い作物を用いると、設置のためのスペース在要とせず、 春季に泠気の停滞が危惧され防風林やネット告設置しにくい凍籍害の常泊地 带の约木園では有効な手段と考えられる。

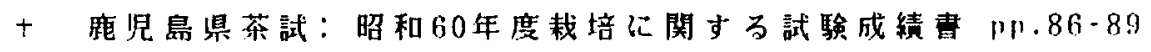


$2-15$ 春挿しにおける遮光方法の違いが苗の生有に及ぼす影喑

久米信夫

\section{(埼玉県茶業試験場)}

埼玉県においては現在苗木の量産が求められているが、県内の供給を增加 させる一方法として春插し苗の利用が考えられる。しかし、無灌水密䦥によ る挿木方法での安定した苗木生産にはまだ改良されるべき点がみられる。こ こでは遮光資材の被覆方法や遮光率の違いがトンネル内温度と苗の生育に及 ほすす影辢について調查した。品種はこまかげを使用し昭和 62 年 4 月 2 日に挿 木した。㨀木床は幅 $1 \mathrm{~m}$ 長さ $4 \mathrm{~m}$ とし、高さ $45 \mathrm{~cm}$ とるように農ボリでカマ ボコ型にトンネルを作った。この捕木床を 2 床使い一方のトンネルには直に、 他の一方には $15 \mathrm{~cm}$ 間隔を取って は 3 枚掛けた。温度测定にはサーミスター温度計を使い両トンネル内床上 5 $\mathrm{cm}$ の気温と地下 $5 \mathrm{~cm}$ 地温、トンネル外地上 $5 \mathrm{~cm}$ 気温を測った。全天日射量 は場内の気象観測露場での観測值を使用した。更に両トンネルの生育比較好 秋期の堀取り調查により行った。

直がけトンネルと間接がけトンネルとの相違点は次のようだった。1)気温 の日変化において直がけトンネルは間接がけトンネルより最高気温は高く最 低気温は低く、地温の日変化は直がけトンネルが間接がけトンネルより高く なった。2)挿木期間中の日平均気温蛙半旬平均值において直がけトンネルが 間接がけトンネルより高く地温む高くなった。3)気温の日較差は直がけトン ネルが間接がけトンネルより大きかった。4)トンネル外最低気温とトンネル 内最低気温の関係では直がけトンネルが間接がけトンネルより冷える程度が やや大きい傾向があった。

寒冷紗 2 枚がけと 3 枚がけの相連点は次のようだった。1)間接がけトンネ ル内の最高気温において は低くなった。2 間接がけトンネル内の日平均気温半旬平均値において寒泠 紗 2 枚ではトンル内が約 $2{ }^{\circ} \mathrm{C}$ 高かったが 3 枚で屾内外の気温が近い值を示 した。

直がけトンネルと間接がけトンネル内での苗の生育差は次のようだった。 1) 5 月までの観察では大きな生育差は見られなかった。6月初めの高温によ り直がけトンネル内の苗が生育阻害を受け秋期の堀取り調查で間接が什卜 ンネルでの苗が優った。2)6月初めの直がけトンネル内の最高気温は $45^{\circ} \mathrm{C} \sim$

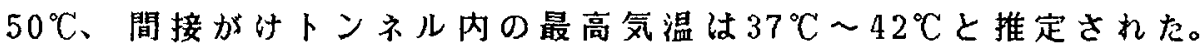

これらの調查結果から直がけトンネルより間接がけトンネルの方が内部の 気温変動が小さく無灌水密䦥による春挿し床の内部環境としてはより適して いると思われた。 
$2-16$ チ十の挿木接ぎにおける穗木 ・台木の組み合わせ 榞田和也・植田和郎・鳥井清孝・澤崎肇

(京都府立茶業研究所)

チャの㨀木接きは、穂木と台木の活着及び台木の発根がられることによ つて成功といえる。そのため，前年度に著者ら沈成功率を高めるために挿木 接きの方法を娭討したところ，約 $80 \%$ 成功率を得た。しかし，成功率には 方法以外に，組み合わせる穗木と台木の品種等が影隌すると考えられる。る こて本試験では，穗木と台木に複数の品種を用いた組み合わせと成功率の関 係について検討した。

\section{（材料及び方法）}

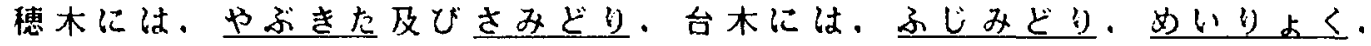

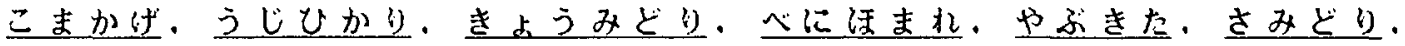

京研96及び京研129 在供試した。㨉木接きは1987及び1988年度に害施し、両 年度とも7月1日前後に挿し木を行い。10月1日前後に穗木と台木の活着及 び台木の発根について調査した。

\section{(結果及び考察)}

1，挿し木接ぎの成功には台木の品䡃が大きく影揞する傾向がみられ，穗木 がどちらの品種てあっても。その成功率に明らかな差はみられなかった。 さらに，成功辩岋1987と1988年度て大きく变動することは認められたが。 台木の品軖・严統との間に一定の傾问がられたので。このことについて 明らかにした。

2 , めいりょく台及びこまか代台は、穂木と台木の活着，台木の発根とも良 好であるため。1987年度の成功害はかなり高く87\%を越えていた。また。

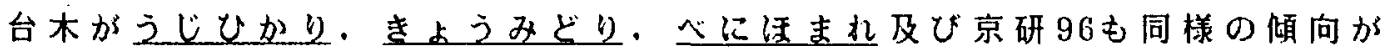
みられ，60〜80\%の成功率が得ら机た。

3，尒じみどり台及び京研 129 台ては、穗木と台木の活着率は75\%以上であ つたが、そのうちの30〜50\%は発根していなかったため。成功宰は40〜60 \%であった。こうしたことには台木の発根率の低さが影部しており、これ らの普通挿しの発根率も50\%以下であり，台木に供試したものの中ではか なり低かった。

4.やぶきた台の発根密は77〜90\%でっったもかかわらず、橞木と台木

の活着が悪いため成功率は39\%以下で最も低いものであった。

以上の結果から，台木に用いる品種の発根率は成功率多決定する大きな要 因であと考えられた。一方，成功菜の年次変動が大きしとから、このこ とを安定させるためには，穗木と台木の品䡃以外の条件についても挨討しな け机ならないと思われた。 
$2-17$ 主根をもつやぶきた苗の接木による育成について

谷田穗

(島根県農業試験埸)

根系改善苗育成の資料を得るため、実生の種子根とやぶきた㯖木との接木 を試み、主根をもつ品種苗を得た。このやぶきた接木苗の生育特性や製茶品 筫などは今後の課題となるが、まずこの接木苗の育成法について報告する。

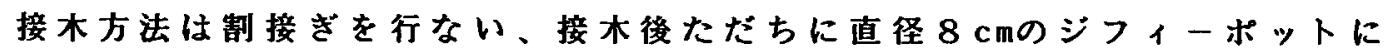
植え、散水後このポットをプランターに入れ、上からサランラップを被せ、 室内に曾いた。活着苗はジフィーポットに植えた状態では場に定植できる。

接穗には、やぶきたの一・二およひ三番茶の芽を用い、二節二葉および 心一葉に調整した。

台木には、あらかしめ発根発芽させておいたやぶた・ふしみどりおよび やまとみどりの実生を用いた。供試部位は、種子根のみ・子葉直下の蕉部を 含む種子根(以下菜付き種子根)およひ子葉の渡芽を除去した子葉以下を含 む種子根（以下二子葉およひ一子葉付き種子根）とした。

接着方法は接木クリップ・接木テープおよひビニールパイプと接木クリッ プとの粗合せ（以下パイプクリップ）とした。ビニールパイプは外径 $6 \mathrm{~mm}$ 径 $3 \mathrm{~mm}$ 長さ約 $10 \mathrm{~mm}$ のものを用い、一力所で蟬割りし、接木接着部を挗んだ。

上記の接慙・台木およひ接着方法を組み合わせて各時期に試験を実施し、 10月15日の調查では以下の結果を得た。

5 月3日の一番茶芽を用いた接木では、接木クリップのみを用いた。二節 二葉接䦄とやふきた実生二子葉付き種子根の組合せで $43 \%$ の生存來を得た。

7 月下旬の二番茶芽を用いた接木では、接穗はすへて二節二葉とした。接 木クリップでの生存率は二子葉付き種子根で高く、やふきた実生では64\%、 やまとみどり実生は57\%であった。接木テープはふしみどり実生の二子葉付 き種子根と種子根のみで試み、前者で57\%媵者では71\%の生存率を得た。

8月下旬の三番茶芽を用いた接木では、接穗はすへて二節二葉、接着法は パイプリップと接木テープ、台木はやぶきたおよひやまとみどりの実生の 二子葉・一子葉およひ藮付きの各種子根を用いた。やふきた実生の場合、三 および一子葉付き種子根では接着法画区ともに100\%の生存本であり、菜付 き種子根ではパイプクリップ区57\%、接木テープ区71\%であった。やまとみ どり実生の場合の生存事は、三子葉付き種子根ではバイフクリップ区71\%、 接木テープ区86\%であり、以下接着方法はこの順に、一子葉付き種子根では それぞ 71\%、100\%、韮付き理子根では29\%、57\%であった。

以上のように、二節二葉接穗・子葉付き種子根・接木テープおよひバイフ クリップの粗合せでは比较的高い生存率が得られたが、引き䊀き模討する。 
$2-18$ 茶秋芽の腐葉土が他の作物の生育に及ぼす影響について （第 1 報）

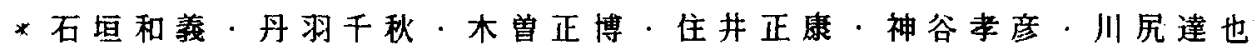
(岥阜県農業棇合研究センタ一)

秋整枝によつて得られる茶葉の有効利用を目的に、茶葉で腐葉土を試作し、

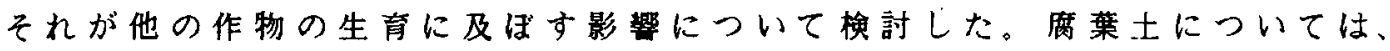
茶葉のみ、茶葉にナタネ粕を重量比で $5 \%$ 添加したもの、鵎䔬を $9 \%$ 添加したも のの3種類を $0.5 \mathrm{~m}^{2}$ の容器内に一年間堆樍し腐化させることにより製造し、そ れぞれ田土と容量比で1:1及び3:7(腐葉土：田土）に混合してキュウリ苗お よびペチュニアの鉢用土として供試し、混合比別にそれぞれ無添加腐葉土区、 ナ夕ネ粕添加腐葉土区、鵎罴添加腐葉土区とした。茶葉による腐葉土と比較 に市販の腐葉土を用い対照区とした。なお、両作物とも肥料の施用は一切行 まず、鉢用土のみで生育させた。

茶葉は一年間堆積することにより添加物の有無に関係なく重望は学、容量 立となった。腐葉土の成分を堆積前の茶原葉と比較すると $T-N 、 K_{2} 0$ は減少す る傾向にあった。 $\mathrm{T}-\mathrm{P}_{2} \mathrm{O}_{5}, \mathrm{Ca}$ 的啋䔬を添加することにより顕著に增加した。 また、市販の腐葉土は茶葉の腐葉土に比べ $\mathrm{T}-\mathrm{N} 、 \mathrm{~K}_{2} 0$ 影著に低かった。

キュウリの播種一月後の地上部、地下部重を調査した結果、混合比 $1: 1$ で の地上部重は対照区の 40〜60倍、地下部重は10〜13倍であった。混合比 $3: 7$ ではやや劣るものの地上部重で23〜30倍、地下部重で5〜8倍で格段の生育を 示した。また、混合比を問かず鵎㶳添加腐葉土区の生育量が多い傾向であっ た。

ペチュニアの開花日における、株の直径、地上部、地下部重を調查した結果、 混合比 1:1での株の直径は対照区の5倍、地上部重は55〜75倍、地下部重は30 倍で、混合比 $3: 7$ では株の直径は 4 倍、地上部重は30〜40倍、地下部重は22〜28 倍の生育量でキュウリと同様の傾向であった。

作付後の鉢用土について分析を行った結果、キュウリ、ペチュニアとも鷄 䔬添加腐葉土区については無添加腐葉土およびナタネ粕添加腐葉土区に比べ $\mathrm{pH}$ 亭く、可粭態 $\mathrm{P}_{2} \mathrm{O}_{5}$ が多かった。これは鵎䔬添加腐葉土の $\mathrm{T}-\mathrm{CaO} 、 \mathrm{P}_{2} \mathrm{O}_{5}$ 含量 が多いためで、鵎基により $\mathrm{CaO} 、 \mathrm{P}_{2} 0_{5}$ の補充が可能であると考えられる。

以上の結果よりキュウリの充苗およびペチュニアの生産に対しては茶葉の 腐葉土を混合した鉢用土を使用することにより施肥を行わなくても十分对応

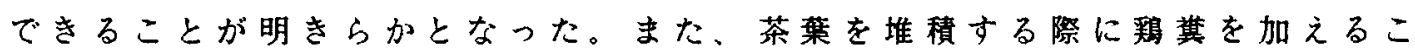
とが腐葉土の肥奻成分を高める上で有効であると考えられた。今媵、適応作 物の拡大、商品化の可能性について梚討する必要がある。 
宮 脇 光 三

（奈良県大和高原農地開発事稀所）

吉 谷一夫

（奈良県天理農業改良㫮及所）

近畿農政局計画部資䃇課による、営農改善技術実証調查の担当した部分に ついて報告する。

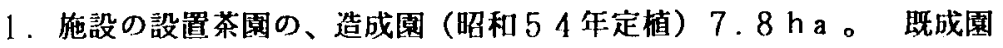
（炤和 51 年定植） $0.5 \mathrm{~h}$ aについて、昭和 54 年から 62 年の 9 年間調查 した。

2. 使用したスブリンクラーは下表の通りである。

\begin{tabular}{|c|c|c|c|c|c|c|c|c|c|}
\hline $\begin{array}{l}\text { のド } \\
\text { の程類 }\end{array}$ & $\begin{array}{c}\text { ハズル } \\
\text { 口径 }\end{array}$ & $\begin{array}{c}\text { ハズ } \\
\text { 角 }\end{array}$ & 吐出量 & 作動日: & $\begin{array}{l}\text { 散水 } \\
\text { 直徍 }\end{array}$ & 殒列 & $\begin{array}{l}\text { 支磕 } \\
\text { 面椟 }\end{array}$ & 支聐かんがい & 使用目的 \\
\hline No. 30 & $\pi$ 常 & 度 & $\ell /$ min & $\mathrm{kg} / \mathrm{cm}^{2}$ & $\pi$ & $m^{2}$ & B & $n \pi / h r$ & 灌水·防除 \\
\hline $\mathrm{L}, \Lambda$ & 1. $4 \times 2.8$ & 14.5 & 26.2 & 2.5 & 24.7 & $12 \times 12$ & 111 & 10.9 & 施肥 \\
\hline No. 30 & & & & & & & & & \\
\hline $\mathrm{EV}$ & 2. 8 & 27.0 & 7.7 & 2.5 & 24.1 & $12 \times 12$ & 144 & 3.2 & 防雷 \\
\hline
\end{tabular}

3. 自動制御䒾置は、造成園を 34 ブロックに区分し、空気作動弁でコン トロールしたが、既成園は電磁弁を手動（防霜は温度計連動の自動）で実施 した。

\section{4. 淍查結果}

1) 防霜調查

(1)最も大きな效果が認められた。(2)地域内で展も早く阴芽する茶園で実施 する場合が経営的に有利である。（晚霜のある年度の初期の茶估は高值であ るため) (3效果は件度に上って差があり、降霜以降の天候が著しく低温の 場合は、全日被覆栽培の方が捎採日が早かった。

\section{2）防除調查}

(1) $10 \mathrm{a} / 400 \ell$ 散布の場合、故障等の監視が不用であれば、集借等の .52 分開で $10 \mathrm{~h} \mathrm{a}$ の防除が可能である。(2)防除は高い均一散布の精度が要 求されるため 700 本以上のへッドの点検調整に多大の時間が必要であった。 (3)調查茶園は倾斜地で明牙绱採期の差が大きいため、春先の萌芽から二番茶 摘採終了まで元混方式の施設は使用できなかった。

3 ) か儿水調查

(1)昭和60 年夏の干ばつ時に、炏芽の伸長に大きな効果がみられた。(2)調查 期間中の一二番茶期は、ほぼ降雨があり目立った効果は見られなかった。

4) 施設の改善

(1)ライザーの自動立上り仕、省力、ゴミ混入防止等の効果が大きかった。 (2)自動制稉を手動切换可能にした改善は、実用上非常に有効で今後設置する 施設には、手動可路を併設するのが望ましい。 


\section{*佐野哲男}

(山梨県南巨摩農業改良普及所)

岩堀源五郎

(農林水産省野莱・茶業試験場)

茶業経営の中で茶園管理作業の省力化の必要性が高まっており，乘用型管 理譏等の大型機械の普及がすすめられている。これらは平坦地の大規模茶園 では省力化において高い性能を示すが,ほ場面積，㑯斜度，経営規模等の制 約により導入困貛な地域も多い。野菜・茶試では, こういった地域での省力 化を目的に,レールを利用してすべての管理作業の軽作業化, 作業精度の高 水準化を可能にする茶園管理装置の開発に取り組んでおり，先に九等・浅井 (1987)がその設置・利用方法について報告している。今回は, レ一ル利用 による摘採方式の作業性能を明らかにするために, 可搬型摘採機による摘採 方式との作業能率，作業精度についての比較を行なったのでここに報告する。

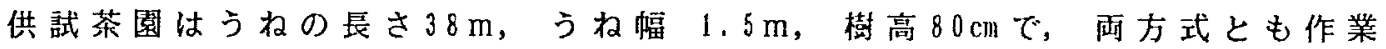
人数は 2 人で摘採を行なった。レール方式による摘採は, 可搬型摘採機を搭 載した台車をイレクターバイブ製のレール上を移動させて行なった。一・二 ・三番茶について，摘採時間，作業時間，生葉の損倠程度，樹冠頂部の摘採 残茎の長さをさらに秋整枝時に整枝重量を調査した。なお，前年の秋整枝， 一、二番茶後の整枝は，各摘採区ともレールを利用して行なった。

10 a当り摘採に要した時間はレール方式が 30 分〜51分, 可搬型摘採機が52 分〜66分で，各茶期ともレール方式が短かった。たた，作業全体の時間は摘 採位置の調整，旋回等に時間を要したレール方式が，三番茶を除いて逆に長 かった。

摘採生葉中の無傷芽はレール方式が54.0\% 73.5\%，可搬型摘採譏が50.2 $\%$ ～ $75.7 \%$ で，一・二番茶ではレール方式がやや少なかったが, 三番茶は多 かった。なお，無傷芽中の $2 \cdot 3$ 葉芽は各茶期ともレール方式が多かった。 また, 離れ葉, 切れ葉（特に細切れ葉）についてはレール方式がやや多い傾 向たった。

残菱長の変動係数は二番茶を除いてレール方式が小さく，秋整枝時の $1 \mathrm{~m}^{2}$ 当りの整枝重量の変動係数もレール方式が小さかった。

以上のことから，レール利用による摘採方式は，摘採能率，则跡の均平度 および新芽の芽ぞろいについては，可搬型摘操機による摘採方式より僈れて いることが明らかになった。したがって,さらに作業機の軽量化，旋回方法 の改善, 生葉の損傷程度の軽減を四れほ，省力摘採方式として中小規模茶園 への導入が可能になると思われる。 
一う极形乗用茶摘採譏性能について

*岩崀勉 - 田中敏弘・山中浩文・荻㥓亮

（鹿児島県茶業試騒場）

松山康甫

(現鹿児島県農業大学校茶業学部)

南九州烟作平坦地域においては、一䁃を往復て摘採する半 う称形乗用茶摘採機（以下半うね形という）战晋及し、省力 化に貢献している。近年、さらに、労力の確保汃困難になり、 一畦应一度に摘採可能な一う好形乗用茶摘㨲機(以下一う极 形という) 加萁入されつつある。そこで、1986〜'87年に一 权形の作業性能について、半う称との比較検討を行った。 調查は、本県知筧町の $\mathrm{K}$ 茶生産組合(以下K組合という)、 $M$ 製茶の各湯で行い、作業能率、作業精度、蛇行検出茈置 の効果、生葉収量について娭討した。

なお、蛇行挨出装置は、作業精度向上のため、 $\mathrm{K}$ 組合では 1986 年一番茶期より、 $\mathrm{M}$ 製茶て は’87年二番茶期より装着さ れ。

（1）作業能率 $\mathrm{K}$ 組合の一う稀形作業量は $38.2 \mathrm{a} / \mathrm{h}$ 、 湯作業量は24.1 a/hで半う的形に比べ、旋回時間や袋脱着 時間も短く、作業能率は約 2.3 倍と能率的でった。

(2)作業精度 $\mathrm{k}$ 組合の半うれ形と一う权形て摘採され た生葉中の古葉木荎混入量について比較したが、両者に有 意差は認わられなかった。

(3) 蛇行検出装置 $の$ 効果

蛇行程度は、 $M$ 製茶の一番茶 装置無し）、四番䒩（装置直り）の晆中央に対象な60cm離机 た2点間 $の$ 摘み残し高の差て比較した。その結果、蛇行梚出 装置の有無に上る有意差加認めら机蛇行減少に役立つた。 また、 $\mathrm{k}$ 組合、 $\mathrm{M}$ 制茶の一番茶の生葉中の古葉木茎混人 量に有意差が認められ、装着により作業精度が向上した。 (4)生葉収量

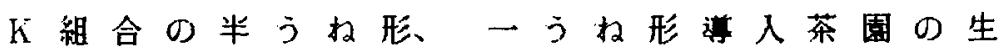
葉収量多比較した。一うね形余入菜園の夏茶てやや少ない 傾向であったが、両者心有意な差は認めら执なかった。 以上、一う权形蚂半う好形に比へ、作業能率は約 2.3 倍と 能率的で直り、作業精度汇屯有意差はない。また、驼行検出 装置着により、作業精度沈さらに向上した。収量について 注有意差は認められなかつた。 